\title{
UPAYA KONSERVASI EKOSISTEM HUTAN RAWA GAMBUT
}

\author{
Antonius \\ Fakultas pertanian Universitas Kapuas Sintang \\ E-mail: anton1975_gurung@yahoo.co.id
}

\begin{abstract}
ABSTRAK: Menurut Puslittanak (1981) luas lahan gambut di Indonesia adalah 26,5 dan luas tersebut terus mengalami penurunan akibat alih fungsi lahan, illegal logging, kebakaran dan pemukiman baru. Lahan gambut merupakan suatu ekosistem yang unik, dan rapuh (fragile), habitatnya terdiri dari gambut dengan kedalaman yang bervariasi mulai dari $25 \mathrm{~cm}$ hingga lebih dari $15 \mathrm{~m}$, mempunyai kekayaan flora dan fauna yang khas yang mempunyai nilai ekonomi tinggi. Lahan gambut mempunyai peran yang penting dalam menjaga dan memelihara keseimbangan lingkungan kehidupan, baik sebagai reservoir air, rosot dan carbon storage, perubahan iklim serta keanekaragaman hayati yang saat ini eksistensinya semakin terancam. Sehingga, pegelolaan secara bijaksana harus dilakukan dengan mempertimbangkan aspek sosial, ekonomi dan budaya maupun fungsi ekologi sehingga kelestarian hutan rawa gambut dapat terjamin. Lahan gambut mempunyai karakteristik yang spesifik seperti adanya subsidensi, sifat irreversible drying, hara mineral yang sangat miskin serta sifat keasaman yang tinggi dan mudah terbakar apabila dalam keadaan kering, sehingga peran hidrologi/tata air di lahan gambut sangatlah penting. Ada beberapa tipologi di lahan rawa gambut yang perlu diketahui, sehingga dalam melakukan rehabilitasi hutan rawa gambut terdegradasi dapat lebih berhasil. Pelestarian hutan rawa gambut dengan segala nilai kekayaan biodiversity harus segera ditindaklanjuti dengan nyata, dengan merehabilitasi lahan gambut yang terdegradasi, baik hidrologi maupun revegetasi. Pemilihan jenis yang tepat, teknologi dan kelembagaan rehabilitasi perlu dikaji dan diketahui sehingga kegagalan dalam melakukan rehabilitasi dapat dihindari. Lahan sulfat masam aktual merupakan salah satu lahan konservasi yang memerlukan jenis yang spesifik untuk dapat hidup di situ, karena adanya senyawa pirit yang bersifat racun. Jenis yang dapat tumbuh antara lain : gelam (Melaleuca sp.), tanah-tanah (Combretocarpus rotundatus) dan lain-lain.
\end{abstract}

Kata kunci : Ekosistem, Hutan rawa gambut, Konservasi.

\section{PENDAHULUAN}

Kerusakan hutan alam atau lahan rawa gambut di Indonesia umumnya disebabkan beberapa hal yakni penebangan liar, perambahan, kebakaran hutan dan lahan gambut, pembuatan saluran atau drainase di lahan gambut yang tidak diperhitungkan dengan baik, lemah dan kurangnya kesadaran dan pengertian masyarakat akan fungsi manfaat hutan rawa gambut, masih lemahnya penegakan hukum (law enforcement) serta masih lemahnya policy dan pengelolaan hutan rawa gambut. Selain itu, sifat kharakteristik hutan rawa gambut seperti adanya 
subsidensi lahan gambut, sifat irreversible drying dan lain-lain sehingga pengelolaan air merupakan hal yang penting. Oleh karena itu kegiatan peneltian integratif aspek-aspek tersebut perlu diteliti untuk pengelolaan hutan dan lahan gambut secara lestari. Kawasan Hutan Wisata Baning yang merupakan ekosistem hutan rawa gambut telah mengalami banyak gangguan, seperti adanya subsidensi gambut, kebakaran hutan, adanya drainase yang mempercepat lajunya air keluar dari kawasan dan penyerobotan lahan oleh masyarakat.

Hutan rawa gambut mempunyai peran penting dalam menjaga dan memelihara keseimbangan lingkungan hidup, baik sebagai reservoir air, rosot dan carbon storage, perubahan iklim serta keanekaragaman hayati yang saat ini eksistensinya semakin terancam (Daryono, 2009). Sifat gambut yang irreversibel drying akan mudah terbakar, sehingga peran hidrologi/tata air di dalam lahan gambut memiliki peranan yang sangat besar dan sangat menentukan keberlangsungan hutan rawa gambut. Keberlangsungan ekosistem hutan rawa gambut yang memiliki nilai konservasi tinggi sesuai dengan fungsinya, karena memiliki keaslian dan keunikan alamnya. Hendaknya dilakukan pengelolaan yang tepat, tidak saja dari aspek ekologis semata, namun perlu mengkaji dukungan publik sesuai dengan isu yang relevan saat ini (Laura, et al. 2016). Sikap masyarakat memiliki implikasi besar terhadap manajemen spesies dalam hal pencegahan, peringatan dan keberhasilan melindungi berbagai spesies yang ada.

\section{KONSERVASI EKOSISTEM HUTAN RAWA GAMBUT}

\subsection{Ekosistem Hutan Rawa Gambut}

Lahan rawa gambut di daerah tropis mencakup areal seluas 38 juta ha dari total seluas 200 juta ha yang terdapat di seluruh dunia. Luas lahan gambut di Indonesia diperkirakan terdapat antara 13,5-26,5 juta ha. Paling sedikit ada 11 dari berbagai sumber data yang bervariasi. Berikut tabel luasan lahan gambut dari berbagai sumber. 
Upaya Konservasi Ekosistem Hutan Rawa Gambut

Tabel 2.1. Luas sebaran lahan rawa gambut di Indonesia dari berbagai sumber

\begin{tabular}{|c|c|c|c|c|c|}
\hline \multirow[b]{2}{*}{ Penulis/sumber data } & \multicolumn{4}{|c|}{ Penyebaran lahan gambut (Juta } & \multirow[t]{2}{*}{ Total $\quad$ (Juta } \\
\hline & Sumatera & Kalimant & Papua & Lainny & \\
\hline Driessen (1978) & 9,7 & 6,3 & 0,1 & - & 16,1 \\
\hline Puslittanak (1981) & 8,9 & 6,5 & 10,5 & 0,2 & 26,5 \\
\hline Euroconsult (1984) & 6,84 & 4,93 & 5,46 & - & 17,2 \\
\hline Soekardi dan Hidayat & 4,5 & 9,3 & 4,6 & 0,1 & 18,4 \\
\hline Deptrans (1988) & 8,2 & 6,8 & 4,6 & 0,4 & 20,1 \\
\hline Subagyo et. al. (1990) & 6,4 & 5,4 & 3,1 & - & 14,9 \\
\hline Deptrans (1990) & 6,9 & 6,4 & 4,2 & 0,3 & 17,8 \\
\hline Nugroho et. al. (1992) & 4,8 & 6,1 & 2,5 & 0,1 & 13,5 \\
\hline Rajaguguk (1993) & 8,2 & 6,79 & 4,62 & 0,4 & 20,1 \\
\hline Dwiyono dan Rachman & 7,16 & 4,34 & 8,40 & 0,1 & 20,0 \\
\hline Wahyunto et. al. (2005) & 7,21 & 5,79 & 8,0 & - & 21,0 \\
\hline
\end{tabular}

Tanah gambut selalu terbentuk pada tempat yang kondisinya jenuh air atau tergenang, seperti pada cekungancekungan daerah pelembahan, rawa bekas danau, atau daerah depresi/basin pada dataran pantai diantara dua sungai besar, dengan bahan organik dalam jumlah banyak yang dihasilkan tumbuhan alami yang telah beradaptasi dengan lingkungan jenuh air. Penumpukan bahan organik secara terus menerus menyebabkan lahan gambut membentuk kubah (peat dome).

Pada hutan rawa gambut, pembentukan kubah gambut (peat dome) di bagian tengahnya mula-mula diawali oleh pembentukan gambut topogen lalu diikuti oleh pembentukan gambut ombrogen di atasnya, yang tidak lagi memperoleh pasokan hara dari air tanah maupun air sungai. Dalam pembentukan gambut ombrogen, klimaks vegetasi bergantian tumbuh dan mati disitu, sehingga semakin tebal gambut, semakin miskin jenis vegetasi yang tumbuh di atasnya, karena pasokan hara sematamata hanya berasal dari air hujan. Bergerak dari pinggiran kubah gambut, dimana gambut masih dangkal, terdapat "mixed forest" yang terdiri dari pohonpohon kayu yang besar-besar dan tumbuhan bawah yang lebat. Berikut adalah gambar formasi hutan rawa gambut. 


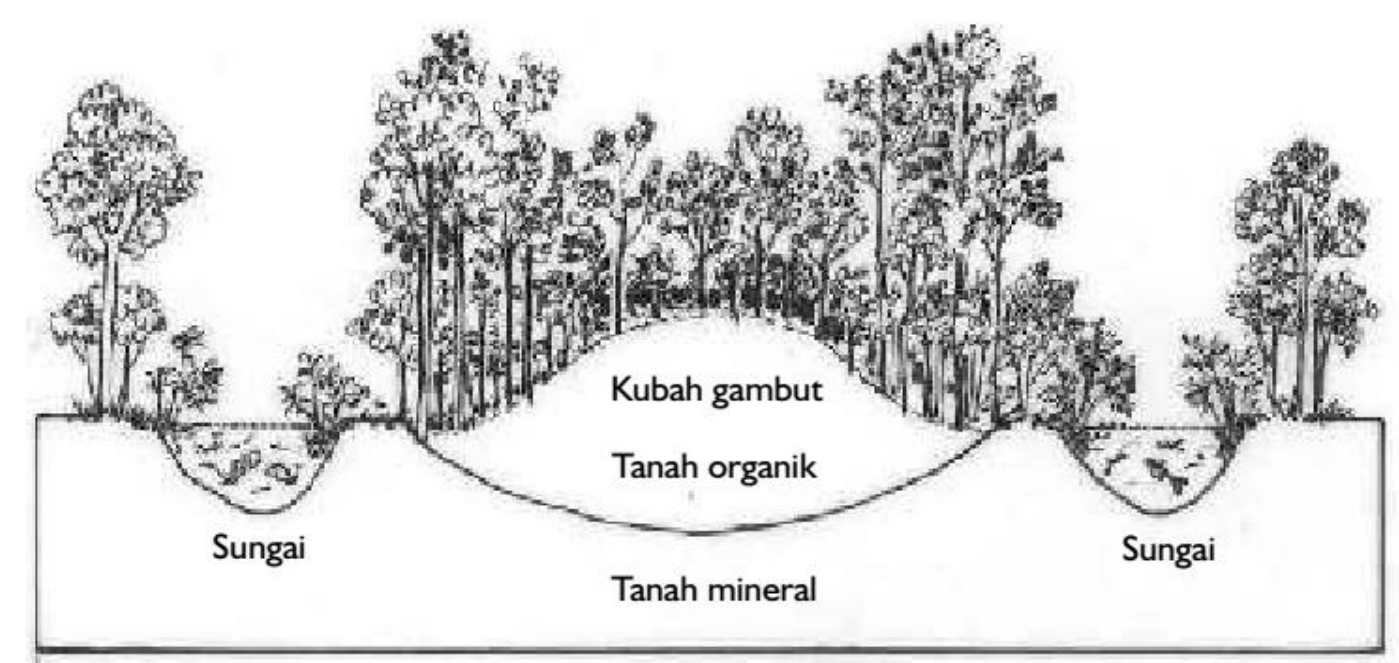

Gambar 2.1. Formasi Hutan Rawa Gambut Dari Tepi Sungai Ke Kubah Gambut

Ke arah pusat kubah, sejalan dengan permukaan gambut yang menaik, terdapat "deep peat forests" dimana vegetasinya semakin jarang dan kurang jenis-jenis tumbuhannya disebabkan karena gambut semakin tebal dan tidak lagi memperoleh hara dari air tanah/sungai. Di pusat kubah di mana gambut paling tebal, terdapat "padang forests" terdiri dari pohon-pohon kayu kecil dan jarang, pandan dan semaksemak. Perubahan dari "mixed forests" ke arah "deep peat forests" terdapat pada kedalaman gambut sekitar 3 m (Widjaya, Adhi, 1986). Di lapangan, kenaikan permukaan kearah pusat kubah seringkali tidak terasa, ini disebabkan oleh karena diameter kubah gambut dapat mencapai 3-10 kilometer, sedangkan kenaikan ketinggian permukaan tanah hanya beberapa centimeter untuk setiap jarak 100 meter.

\subsection{Keanekaragaman Hayati} Ekosistem Hutan Rawa Gambut

Dari hasil penelitian yang dilakukan baik di Pulau Sumatera maupun di Kalimantan, habitat rawa gambut mengandung kekayaan keanekaragaman yang tinggi untuk jenis flora dan fauna, reservoir/simpanan air, dan simpanan karbon. Kekayaan flora yang berisi bermacam-macam jenis pohon yang kayunya mempunyai nilai komersial tinggi untuk keperluan bahan industri meubel dan konstruksi. Selain itu juga terdapat berbagai jenis pohon yang mempunyai nilai komersial dari hasil hutan non kayu baik berupa getah, lateks, kulit pohon, bahkan mempunyai 
kandungan zat ekstraksi yang berguna untuk kepentingan obat-obatan (medicinal plants). Jenis-jenis pohon rawa gambut yang memiliki potensi strategis seperti bintangur (Calophyllum lanigerum) yang mempunyai zat bioaktif untuk anti virus HIV. Jenis bintangur lainnya adalah Calophyllum cannum dan C.dioscorii yang mempunyai zat bioaktif anti kanker dan masih ada lagi beberapa jenis prospektif lainnya. Di masa depan, nilai ekonomi zat bioaktif ini akan jauh lebih tinggi dari pada nilai kayunya. Beberapa pohon penting yang kayunya mempunyai nilai komersial tinggi, seperti Ramin (Gonydtylus bancanus), Pulai Rawa (Alstonia pnematophora), Prupuk (lLopopethalum javanicum), Katiau (Ganua motleyana), Sonte (Palaquium leicocarpum), Meranti bunga (Shorea teysmanniana), Meranti rawa (Shorea pauchiflora), Jelutung rawa (Dyera lowii), Terentang (Campnosperma auriculata), dan banyak lagi jenis lainnya. Sedangkan jenis-jenis pohon yang mempunyai nilai penting yang menghasilkan hasil hutan non kayu (non woodforest products) antara lain Gimor (Alseodaphne hellophylla), Sonte (Palaquium leicocar pum), Nyatoh
(Palaquium gutta), Jelutung (Dyera lowii), Pulai (Alstonia pnematophora), Bintangur (Calophyllum spp) dan Bintangur (Calophyllum spp).

Fauna yang spesifik yang ada di hutan rawa gambut di antaranya adalah orang utan (Pongo pygmaeus), bakantan (Nasalis larvatus), beruang madu (Helarctos malayanus), owa (Hylobates agilis), burung rangkong (hornbills), macan daun, monyet ekor panjang (Macaca fascicularis) dan lain-lain. Di hutan rawa gambut yang ketebalan gambutnya sangat dalam, terdapat suatu ekosistem air hitam dengan biota yang spesifik yakni adanya fitoplankton Cosmarium sp, dan Peridium sp yang hanya ada di ekosistem air hitam. Laporan dari Britain Royal Society yang dipublikasikan pada akhir Januari 2006, melaporkan bahwa, telah diketemukan seekor ikan dewasa yang terkecil di dunia berukuran panjang $1 / 3$ inch $(8,5 \mathrm{~mm})$ dan saat ini spesimennya berada di National History Museum, yang diperoleh dari hutan rawa gambut bekas terbakar di Sumatera. Hal ini bukan saja ikan terkecil tetapi juga vertebrata dewasa terkecil di dunia.

\subsection{Pembentukan Tanah Gambut}


Upaya Konservasi Ekosistem Hutan Rawa Gambut

Secara umum, tanah gambut adalah tanah-tanah yang tersusun dari bahan tanah organik yang jenuh air dengan ketebalan $50 \mathrm{~cm}$ atau lebih. Dikaitkan dengan ketebalan bahan organik, maka tanah mineral yang mempunyai lapisan gambut di permukaan 20 - $50 \mathrm{~cm}$ disebut sebagai tanah mineral bergambut (peaty soil). Dikatakan sebagai tanah mineral murni apabila lapisan gambut dipermukaaan < $20 \mathrm{~cm}$. Dalam klasifikasi tanah lama, tanah gambut disebut organosol. Tingkat dekomposisi atau pelapukan/perombakan bahan organik gambut, dibagi menjadi 3 tingkatan, yaitu fibrik (awal), hemik (tengah) dan saprik (lanjut). Fibrik adalah gambut dengan tingkat dekomposisi awal yaitu kandungan serat tumbuhan lebih dari $75 \%$, atau masih lebih dari tiga perempat bagian dari volumenya. Sedang hemik adalah gambut dengan tingkat dekomposisi tengahan, yaitu kandungan serat $17-75 \%$ atau tinggal antara 1/6-3/4 bagian volumenya. Saprik adalah gambut dengan tingkat dekomposisinya yang lanjut, yaitu kandungan seratnya kurang dari $17 \%$ atau tinggal kurang dari $1 / 6$ bagian dari volumenya. Gambut saprik biasanya berwarna kelabu sangat gelap hitam. Sifat- sifatnya (sifat fisik maupun kimianya) relatif sudah stabil. Berikut adalah warna tanah gambut berdasarkan tingkat kematangannya.

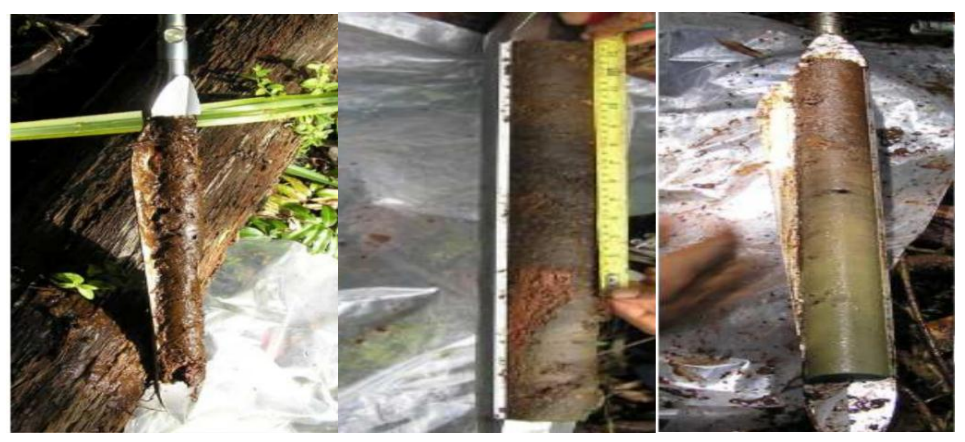

Gambar 2.2. Berturut-turut gambut fibrik, hemic dan saprik

Dari hasil pengamatan, pada umumnya degradasi hutan rawa gambut dapat dilihat dari kerusakan tegakannya maupun kondisi subsidensi gambutnya.
Hutan rawa gambut yang mengalami kerusakan tegakan karena pembalakan berlebihan, pembalakan liar, perambahan maupun mengalami kebakaran 
akan mengubah ekosistem hutan rawa gambut tersebut menjadi belukar, semak atau bahkan terbuka (open area). Hal ini akan menentukan model restorasi atau rehabilitasi lahan tersebut. Demikian juga pada hutan rawa gambut yang telah dilakukan eksploitasi menurut kaidah yang benar, pada tegakan tinggal dapat dilakukan dengan pembinaan regenerasi alam atau dengan penanaman pengkayaan.

Berdasarkan lingkungan pembentukannya, tanah gambut dibedakan menjadi : (a) tanah gambut ombrogen, terbentuk pada lingkungan yang hanya bergantung pada air hujan, tidak terkena pengaruh air pasang, membentuk suatu kubah (dome) dan umumnya tebal, dan (b) tanah gambut topogen, terbentuk pada bagian pedalaman dari dataran pantai/sungai yang dipengaruhi oleh limpasan air pasang/banjir yang banyak mengandung mineral, sehingga relatif lebih subur, dan tidak terlalu tebal. Tanah gambut topogen dikenal sebagai gambut eutropik, sedangkan tanah gambut ombrogen dikenal sebagai tanah gambut oligotrofik dan mesotrofik.

\subsection{Hidrologi Hutan Rawa Gambut}

PIPER No. 23 Volume 12 Oktober 2016
Untuk dapat dimanfaatkan, lahan gambut harus dilakukan reklamasi yang diawali dengan drainase dan land clearing. Seperti telah disebutkan di atas, salah satu sifat gambut yang menyebabkan sulitnya pengelolaan dan rehabilitasi lahan adalah irreversible drying atau non re wetable. Oleh karena itu, sekali mengalami kekeringan sampai tingkat tertentu maka gambut tidak bisa terbasahkan kembali. Hal ini mengakibatkan volume gambut akan menyusut, sehingga akan mengakibatkan penurunan permukaan tanah gambut (subsidence/subsiden).

Kecepatan subsiden dipengaruhi oleh banyak faktor, antara lain tingkat kematangan gambut, tipe gambut, kecepatan dekomposisi, kepadatan dan ketebalan gambut, kedalaman drainase, iklim, serta tipe penggunaan lahan (Wösten et al., 1997). Dradjat et al (1986) dalam Rina et al. (2008) melaporkan laju amblesan 0,36 $\mathrm{cm} /$ bulan pada tanah gambut saprik di Barambai (Kalimantan Selatan) selama 12-21 bulan setelah reklamasi, sedang untuk gambut saprik di Talio (Kalimantan Tengah) lajunya 0,178 $\mathrm{cm} /$ bulan dan bahan gambut hemik 0,9 $\mathrm{cm} /$ bulan. Penurunan muka lahan di 
Desa Babat Raya dan Kolam Kanan

Kecamatan Barambai Kalimantan

Selatan mencapai antara 75-100 cm dalam masa 18 tahun (April 1978September 1996) (Noorginayuwati et al. 2006).

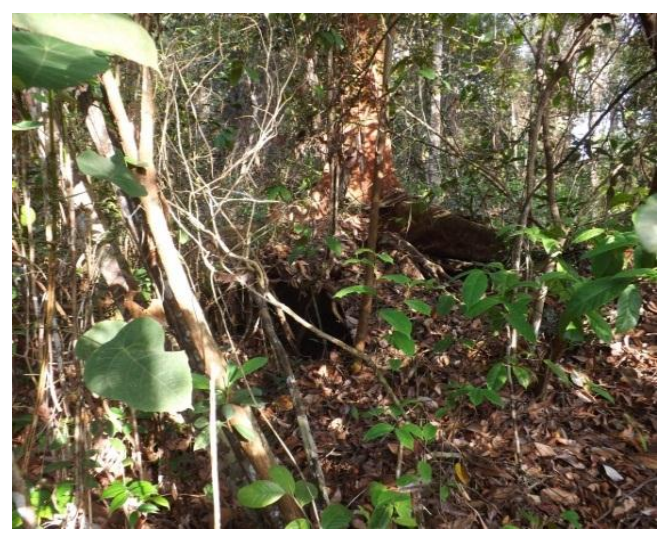

Gambar 2.3. Perakaran Pohon Menggantung Akibat Subsidensi Tanah Gambut

Menurut Agus dan Subiksa (2008), proses subsiden gambut dapat dibagi menjadi empat komponen:

1. Konsolidasi yaitu pemadatan gambut karena pengaruh drainase. Penurunan muka air tanah menyebabkan terjadinya peningkatan tekanan dari lapisan gambut di atas permukaan air tanah terhadap gambut yang berada di bawah muka air tanah sehingga gambut terkonsolidasi (menjadi padat).

2. Pengkerutan yaitu pengurangan volume gambut di atas muka air tanah karena proses drainase / pengeringan.
3. Dekomposisi/oksidasi yaitu menyusutnya massa gambut akibat terjadinya dekomposisi gambut yang berada dalam keadaan aerobik.

4. Kebakaran yang menyebabkan menurunnya volume gambut.

\subsection{Simpanan Karbon Di Hutan Rawa Gambut}

Dalam keadaan hutan alami yang tidak terganggu, lahan gambut merupakan penyerap (sink) $\mathrm{CO}_{2}$. Menurut Agus (2008), simpanan karbon terbesar pada lahan gambut adalah pada gambut itu sendiri dan yang kedua adalah pada jaringan tanaman dan pada 
serasah. Masing-masing simpanan karbon tersebut dapat bertambah atau berkurang tergantung pada faktor alam dan campur tangan manusia. Kemarau panjang berakibat pada penurunan muka air tanah yang selanjutnya mempercepat emisi $\mathrm{CO}_{2}$. Kebakaran dapat menurunkan simpanan karbon di jaringan tanaman dan di dalam gambut. Pemupukan dapat meningkatkan emisi. Sebaliknya, pada lahan gambut yang sudah terlanjur didrainase, peningkatan muka air tanah, misalnya melalui pemasangan empang pada saluran (canal blocking) dapat memperlambat emisi.

Apabila hutan gambut terganggu, maka lahan gambut berubah fungsi dari penyerap menjadi sumber emisi gas rumah kaca (Agus dan Subiksa, 2008). Gas rumah kaca (GRK) yang dikeluarkan (diemisikan) lahan gambut adalah $\mathrm{CO}_{2}, \mathrm{CH}_{4}$ (metan), dan $\mathrm{N}_{2} \mathrm{O}$. Di antara ketiga gas tersebut $\mathrm{CO}_{2}$ merupakan GRK terpenting karena jumlahnya yang relatif besar, terutama dari lahan gambut yang sudah berubah fungsi dari hutan menjadi lahan pertanian dan pemukiman. Jumlah emisi dari tanah gambut untuk selang waktu tertentu dapat dihitung berdasarkan perubahan karbon tersimpan pada tanah gambut.

\subsection{Konsep Pelestarian Hutan Rawa Gambut}

Menurut Keppres No.32/1990 tentang Kawasan Lindung dan Undangundang No. 26 tahun 2007 tentang Penataan Ruang (UUTR), serta petunjuk penyusunan Rencana Tata Ruang Wilayah Nasional RTRWN, kawasan tanah gambut dengan ketebalan $3 \mathrm{~m}$ atau lebih, yang terdapat di bagian hulu sungai dan rawa, ditetapkan sebagai kawasan lindung bergambut. Perlindungan terhadap kawasan ini dilakukan untuk mengendalikan hidrologi wilayah, berfungsi sebagai penambat air dan pencegah banjir, serta melindungi ekosistem yang khas di kawasan tersebut. Kubah gambut dengan ketebalan lebih dari $3 \mathrm{~m}$ merupakan satu kesatuan dengan bagian tepinya yang dangkal (ketebalan kurang dari $3 \mathrm{~m}$ ). Pengelolaan lahan rawa gambut perlu menerapkan pendekatan konservasi, yang meliputi perlindungan, pengawetan, dan peningkatan fungsi dan manfaat. Oleh karena itu, berdasarkan fungsinya wilayah rawa dibedakan ke dalam: (1) kawasan lindung, (2) kawasan 
pengawetan, dan (3) kawasan reklamasi untuk peningkatan fungsi dan manfaat. Kawasan lindung dan pengawetan disebut juga kawasan nonbudi daya, sedangkan kawasan reklamasi disebut kawasan budi daya. Wilayah rawa yang termasuk sebagai kawasan lindung adalah: (1) kawasan gambut sangat dalam, lebih dari $3 \mathrm{~m}$; (2) sempadan pantai; (3) sempadan sungai; (4) kawasan sekitar danau rawa; dan (5) kawasan pantai berhutan bakau. Kawasan pengawetan atau kawasan suaka alam adalah kawasan yang memiliki ekosistem yang khas dan merupakan habitat alami bagi fauna dan/atau flora tertentu yang langka serta untuk melindungi keanekaragaman hayati. Kawasan ini diusulkan untuk dipertahankan tetap seperti aslinya atau dipreservasi dengan status sebagai kawasan non budidaya. Dasar hukum dan kebijakan pemerintah dalam upaya pelestarian hutan rawa gambut adalah sebagaimana tertera pada kalimat berikut ini:

1. Keppres 32/1990 Pengelolaan Kawasan Lindung

2. PP 26 Thn 2008 Tentang RTRWN
3. Undang-undang No. 32/2009 tentang perlindungan dan pengelolaan $\mathrm{LH}$

4. RTRW berbasis KLHS, daya dukung, dan daya tampung lingkungan hidup

5. Pengendalian kebakaran hutan/lahan (gambut)

6. Penurunan emisi GRK (Gas Rumah Kaca) sebesar $26 \%$

7. Inpres No. 1 th 2010 tentang Percepatan Pelaksanaan Prioritas Pembangunan Nasional tahun 2010.

8. Permentan No. 14/Permentan/PL.110/2/2009

Tentang Pedoman Pemanfaatan Lahan Gambut Untuk Budidaya Kelapa Sawit.

9. Inpres No. 10 Tahun 2011 Tentang Penundaan Pemberian Izin Baru dan Penyempurnaan Tata Kelola Hutan Alam Primer dan Lahan Gambut, yang saat ini telah mengalami revisi hingga revisi ke 8.

10. Perpres No. 61 Tahun 2011 Tentang Rencana Aksi Nasional Penurunan Emisi GRK.

11. Perpres No.71 Tahun 2011 Tentang Penyelenggaraan Inventerisasi GRK Nasional. 
12. Strategi Nasional Pengelolaan

Ekosistem Gambut .
13. RPP Perlindungan dan Pengelolan Ekosistem Gambut.

\section{DAFTAR PUSTAKA}

Agus, F., dan Subiksa, IGM. 2008. Lahan Gambut: Potensi Untuk Pertanian dan Aspek Lingkungan. Balai Penelitian Tanah. Bogor.

Ashton P.S. 2009. Conservation of Borneo biodiversity: do small lowland parks have a role, or are big inland sanctuaries sufficient? Brunei as an example. Biodiversity and Conservation: P 1. 343-356.

BAPPENAS-PHPA-The World Bank. 3. The World Bank. 1997. Investing in Biodiversity: A Review of Indonesia's Integrated Conservation and Development Projects. The World Bank Indonesia and Pacific Islands Development Departement.

Bismark M. 2014. Model pengelolaan Kawasan Konservasi Berbasis Ekosistem, Jakarta. Indonesia.

Catherine M. Y and Lalita N. Gomez. 2009. Leaf Litter Decomposition In A Tropical Peat Swamp Forest In Peninsular Malaysia. Wetland Ecol Manage. 17: 231-241. 
